\title{
PENGARUH PERMAINAN TRADISIONAL ENGKLEK TERHADAP PERKEMBANGAN KOGNITIF ANAK USIA 5-6 TAHUN
}

\author{
Dwi Ana Pertiwi \\ Siti Fadjryana Fitroh \\ Dewi Mayangsari \\ Program Studi Pendidikan Guru Pendidikan Anak Usia Dini Fakultas Ilmu Pendidikan \\ Universitas Trunojoyo Madura \\ Email: dwiana17@gmail.com, stfadjryana@gmail.com, mayangsarie@gmail.com
}

Received August 2018, Accepted September 2018, Published October 2018

\begin{abstract}
This study aims to determine the effect of traditional games on children cognitive development aged 56 years in TK Tarbiyatul Athfal Jaddih, Socah District Bangkalan rege. The game is able to increase affiliation with peers, reduce stress, and improve cognitive development. This game has been proved to increase affiliation with peers, reduce the pressure, and improve children cognitive development. This "englek" traditional games is utilized to stimulate cognitive development in the naming of numbers 1-20 and match numbers with symbols of numbers. This research employed quantitative method with Pre-experimental approach in the form of one group pretestposttest. Subjects in this study were 11 students aged 5-6 years in kindergarten Tarbiyatul Athfal. The data collection was carried out by conducting observation and documentation in the form images of the activities and daily lesson plan. Data analysis was executed by conducting statistical analysis technique of parametris in the form of t-test with data gathered from the result of pretest and posttest. The results obtained at the pretest, there were 2 children have low score and 9 children have been successfully on middle score. The Posttest was carried after giving treatment using "engklek" traditional game found 2 children started to grow, 5 children developed as expected, and 4 children developed very well. The result of $t$-test showed that the value $t_{\text {count }} i s-5,83$ and $t_{\text {table }}$ 2,086, then -2,086> -5,83 so that Ha was accepted. This finding shows that there is a significant effect of "englek" traditional game on children cognitive development aged 5-6 years in TK tarbiyatul athfal jaddih, Socah District Bangkalan Regency.
\end{abstract}

Keywords: Traditional Games, Cognitive Development, Children Aged 5-6 Years.

Abstrak: Penelitian ini bertujuan untuk mengetahui pengaruh permainan tradisional engklek terhadap perkembangan kognitif anak usia 5-6 tahun di TK Tarbiyatul Athfal Desa Jaddih Kecamatan Socah Kabupaten Bangkalan. Permainan mampu meningkatkan afiliasi dengan teman sebaya, mengurangi tekanan, dan meningkatkan perkembangan kognitif. Permainan tradisional engklek digunakan untuk menstimulus perkembangan kognitif dalam menyebutkan lambang bilangan 1-20 dan mencocokkan bilangan dengan lambang bilangan. Penelitian ini menggunakan metode kuantitatif dengan pendekatan Pre-experimental Design jenis one group pretest-posttest. Subyek dalam penelitian ini adalah anak didik dengan rentang usia 5-6 tahun di TK Tarbiyatul Athfal dengan jumlah 11 anak. Peneliti menggunakan teknik pengumpulan data observasi partisipan dan dokumentasi berupa foto-foto kegiatan dan rencana pelaksanaan pembelajaran harian. Peneliti menggunakan teknik analisis data statistik parametris berupa uji-t dengan data hasil penilaian pretest dan posttest. Hasil penelitian ini diperoleh pada saat pretest terdapat 2 anak dengan nilai belum berkembang dan 9 anak mulai berkembang. Penilaian posttest setelah melakukan treatment dengan menggunakan permainan tradisional engklek didapatkan 2 anak mulai berkembang, 5 anak berkembang sesuai harapan, dan 4 anak berkembang sangat baik. Hasil perhitungan dengan menggunakan uji-t diperoleh nilai thitung yaitu -5,83 dan nilai tabel sebesar 2,086 maka -2,086>5,83 dan Ha diterima. Berdaraskan analisis tersebut menunjukkan terdapat pengaruh yang signifikan antara permainan tradisional engklek terhadap perkembangan kognitif.

Kata Kunci : Permainan Tradisional Engklek, Perkembangan Kognitif, Anak Usia 5-6 Tahun.

\section{PENDAHULUAN}

Anak usia dini merupakan masa yang tepat untuk melakukan pendidikan. Pada masa ini anak akan sedang mengalami proses pertumbuhan dan perkembangan yang luar biasa (Fadlillah, 2014:21). Untuk itu pendidikan harus dimulai saat anak berusia dini, dimana pendidiklah yang memiliki peranan penting dalam mengoptimalkan perkembangan anak, baik itu perkembangan pribadi, karakter, kemampuan fisik, kognitif, bahasa, seni, sosial, emosional, spiritual, disiplin diri, konsep diri maupun kemandirian anak.

Anak usia dini merupakan individu yang berbeda, unik, dan memiliki karakteristik 
tersendiri sesuai dengan tahapan usianya (Mulyani, 2016:59). Dalam memberikan layanan pendidikan, pendidik perlu memahami karakteristik perkembangan serta cara-cara anak belajar dan bermain. Dimana pada masa usia dini perkembangan seorang anak mengalami perkembangan yang sangat pesat.

Proses pertumbuhan dan perkembangan pada anak usia dini sangat menentukan untuk pengembangan kualitas manusia. Untuk itu pendidikan memiliki tujuan dalam merangsang perkembangan dan pertumbuhan anak, yaitu dengan diselenggarakannya pendidikan formal prasekolah yang dapat dijangkau oleh berbagai lapisan masyarakat. Seperti yang dikemukakan Peraturan Pemerintah Republik Indonesia tahun 2010 pasal 3 bahwa salah satu pendidikan formal prasekolah adalah Pendidikan Anak Usia Dini yang merupakan upaya pembinaan anak dalam pemberian rangsangan untuk meningkatkan perkembangan dan pertumbuhan demi kesiapan anak memasuki jenjang yang lebih lanjut.

Tujuan pendidikan anak usia dini sebagai pemenuhan kebutuhan perkembangan anak dan memberikan pengalaman kepada anak dalam belajar sehingga dapat merangsang anak untuk bersosialisasi yaitu berinteraksi dengan teman sebaya, ataupun yang lainnya. Selain itu pendidikan juga menjadikan kepribadian anak semakin berkembang. Sehingga anak dapat mandiri dan mengoptimalkan berbagai potensinya.

Pengajaran pada pendidikan anak usia dini juga ditekankan memiliki perkembangan kognitif yang baik. Dimana perkembangan kognitif adalah perkembangan dari pikiran. Pikiran adalah bagian dari berpikir dari otak, bagian yang digunakan yaitu untuk pemahaman, penalaran, pengetahuan, dan pengertian (Susanto, 2011:52). Adapun aspek perkembangan kognitif dalam standar pencapaian perkembangan anak (STPPA) pada usia 5-6 tahun dibagi menjadi tiga yaitu belajar dan pemecahan masalah, berfikir logis, dan berfikir simbolik. Dimana berfikir simbolik adalah berfikir dengan menggunakan penalaran untuk mengetahui dan memahami melalui simbol-simbol. Seperti yang di tetapkan STPPA dalam berfikir simbolik anak usia 5-6 tahun dapat menyebutkan lambang bilangan dan mencocokkan bilangan dengan lambang bilangan. Maka diperlukan media dan teknik pembelajaran yang baik agar anak mudah mengingat setiap lambang bilangan dan mencocokkannya. Mencocokkan merupakan sesuatu yang membandingkan untuk mengetahui cocok atau tidaknya sesuatu, dimana anak mampu mencocokkan bentuk, warna, ukuran, bilangan, pola, dan lain-lain.

Faktor kognitif mempunyai peranan penting bagi keberhasilan dalam belajar anak, karena sebagian besar aktivitas dalam belajar selalu berhubungan dengan masalah mengingat dan berfikir. Kedua aktifitas ini merupakan aktivitas kognitif baik itu dalam mengingat bentuk, warna, pola, ukuran, konsep, huruf maupun lambang bilangan. Kemampuan ini dapat dilihat dari kemampuan anak dalam konsep bilangan yaitu dengan menyebutkan lambang bilangan dan mencocokkannya. Oleh karena itu perkembangan kognitif anak perlu dirangsang dan dikembangkannya sejak dini. Seperti yang dikemukakan oleh Piaget mengenai perkembangan kognitif. Perkembangan kognitif menurut Piaget salah satu teori yang menjelaskan bagaimana anak beradaptasi dengan dan menginterpretasikan objek dan kejadian-kejadian di sekitarnya (Desmita, 2015: 46).

Faktor kognitif mempunyai peranan penting bagi keberhasilan dalam belajar anak, karena sebagian besar aktivitas dalam belajar selalu berhubungan dengan masalah mengingat dan berfikir. Kedua aktifitas ini merupakan aktivitas kognitif baik itu dalam mengingat bentuk, warna, pola, ukuran, konsep, huruf maupun lambang bilangan. Kemampuan ini dapat dilihat dari kemampuan anak dalam konsep bilangan yaitu dengan menyebutkan lambang bilangan dan mencocokkannya. Oleh karena itu perkembangan kognitif anak perlu dirangsang dan dikembangkannya sejak dini.

Perkembangan kognitif dapat dikembangkan melalui metode bermain. Sebagaimana para ahli menemukan bahwa bermain bukan saja memudahkan anak-anak untuk beradaptasi pada lingkungan sosial dan fisik, tetapi juga memfasilitasi komunikasi anakanak dengan yang lainnya mengenai pemikiran dan perasaan mereka yang berhubungan dengan pemahaman mereka mengenai dunia (Kostelnik dalam Aulina, 2014: 2).

Bermain merupakan kegiatan yang menyenangkan hati. Sementara yang dimaksud belajar adalah berusaha memperoleh kepandaian atau ilmu. (Mulyani, 2016: 59). Dengan adanya konsep belajar sambil bermain akan lebih memudahkan pendidik, karena anak lebih mudah diatur dan anak tidak akan merasa lelah 
serta anak tidak akan merasakan masa bermainnya hilang ketika berada disekolah. Anak juga akan lebih mudah untuk mengaplikasikan pembelajaran yang di dapat di sekolah agar bisa dilakukan pada kegiatan sehari-harinya. Belajar sambil bermain juga memberikan rasa semangat bagi anak dalam menerima pembelajaran. Dimana anak tidak akan merasa bosan untuk datang ke sekolah.

Sekarang ini banyak alat permainan yang dapat diberikan pada anak. Baik permainan yang sifatnya tradisional ataupun permainanpermainan yang lebih modern. Permainan tradisional biasanya permainan yang diwariskan oleh para leluhur dan alat yang digunakan dalam permainan menggunakan bahan alam seperti kayu, batu, bambu dan lain sebagainya. Berbeda dengan permainan modern yang sifatnya menggunakan peralatan teknologi yang canggih untuk memainkannya seperti permainan yang terdapat di dalam ponsel ataupun perlatanperalatan yang sifatnya mahal (Kurniati, 2016:1).

Jenis permainan yang beredar di masyarakat sangat bermacam-macam dari mulai permainan yang murah sampai permainan yang mahal, permainan tradisional sampai yang ke permainan modern. Namun, akhir-akhir ini anak senang bermain permainan modern (game) dan permainan tradisional sudah tidak lagi dipakai. Maka itu perlu diperkenalkan kembali kepada anak-anak, tentang permainan tradisional karena dilihat dari manfaatnya yang begitu banyak (Chasanah, 2015: 88).

Permainan tradisional sebagai satu di antara unsur kebudayaan bangsa yang banyak tersebar di berbagai penjuru Nusantara, namun dewasa ini keberadaanya sudah berangsurangsur mengalami kepunahan namun masih ada juga yang bisa bertahan. Terutama bagi mereka yang saat ini tinggal di perkotaan, mereka sudah tidak lagi memainkan permainan tradisional. Mereka lebih memainkan permainan modern yang menggunakan alatalat yang canggih dan lebih mudah didapatkan. Permainan tradisional pada dasarnya permainan yang bersifat sederhana dan mengandalkan kekompakan dari masing-masing peserta dalam kegiatan bermain. Permainan tradisional mulai jarang di mainkan dalam beberapa dekade belakangan ini, hal ini dipengaruhi oleh perkembangan pola pikir dari masyarakat yang semakin maju sehingga meninggalkan kebiasaan-kebiasaan lama yang masih bersifat tradisional ke kebiasaan modern yang serba mudah dan instan. Pemanfaatan permainan tradisional sebagai media pembelajaran masih belum banyak digunakan dalam kegiatan pembelajaran pada anak usia dini. Hal ini dapat disebabkan karena kurangnya pengetahuan mengenai pengaruh positif dari permainan tradisional terhadap pengembangan kemampuan yang dimiliki oleh anak (Gian, 2015).

Permainan tradsional sangat beragam salah satunya permainan tradisonal engklek. Permainan engklek dalam bahasa sunda yaitu sonlah/sondah merupakan permainan yang menutut koordinasi motorik kasar bagi setiap pemainnya. Permainan ini memiliki beberapa bentuk dasar, yaitu sonlah biasa, sonlah jeruk, dan sonlah eser (Kurniati, 2016:91).

Berdasarkan pendapat tersebut dapat dikatakan bahwa permainan tradisional engklek memerlukan koordinasi motorik terutama motorik kasarnya, karena dilakukan dengan loncat-loncatan. Permainan engklek di madura permainannya sama dengan permainan engklek yang ada di jawa maupun di sunda, naum hanya penyebutannya yang berbeda. Engklek yang digunakan dalam penelitian ini adalah pola engklek gunung (seperti terlihat pada gambar 1).

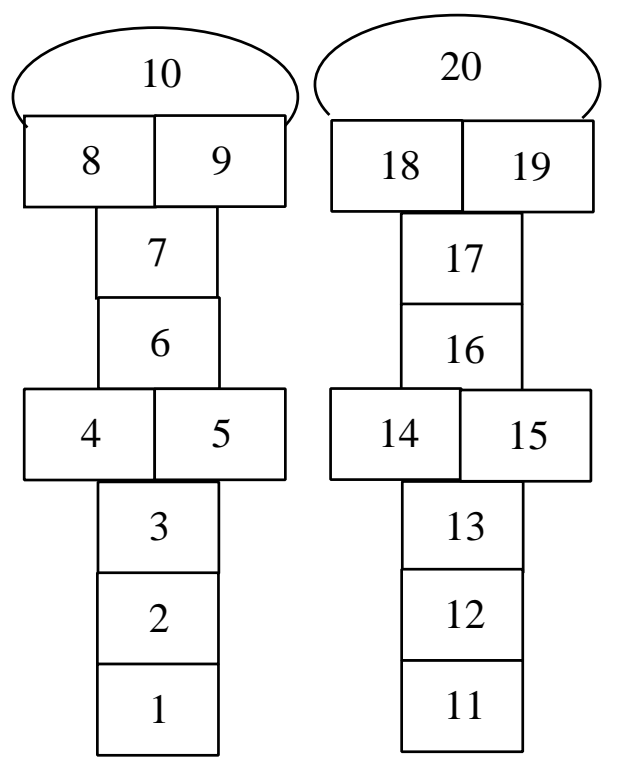

\section{Gambar 1 Pola Engklek Gunung}

Berdasarkan hasil observasi awal di lokasi penelitian pada tanggal 8 Agustus 2017 pengaplikasian permainan tradisional engklek di sekolah sudah pernah dilakukan, namun 
permainan tersebut dijadikan guru sebagai kegiatan bermain saja, tidak menerapkan pembelajaran melalui permainan tradisional. Di TK Tarbiyatul Athfal Jeddih Bangkalan memiliki jumlah anak 15 dengan rentang usia 56 tahun yang berada di kelompok B. Anakanak di TK Tarbiyatul Athfal dalam kemampuan mengenal lambang bilangan masih dikategorikan rendah, sebab anak hanya dapat menyebutkannya saja. Ketika anak dapat menyebutkan lambang bilangan 1-20, bukan berarti semua anak dapat mencocokkan bilangan dengan lambang bilangan 1-20. Salah satu contohnya adalah ketika sekelompok anak yang berjumlah 15 , tetapi hanya 4 anak yang dapat mencocokkan bilangan dengan lambang bilangan dengan benar tanpa bimbingan guru, sedangkan 11 orang anak kurang mampu dan masih membutuhkan bimbingan dari guru.

Pembelajaran yang digunakan di sekolah berpusat pada guru saja, guru tidak mengikutsertakan anak dalam pembelajaran. Selain itu pembelajaran yang dilakukan oleh guru terkesan monoton yang hanya menggunakan papan tulis atau lembar kerja siswa dalam mengajar. Tidak hanya itu, guru juga kurang dalam menggunakan media saat pembelajaran serta kurang menggunakan kegiatan bermain saat pembelajaran berlangsung. Dimana kegiatan bermain dapat membantu minat anak saat belajar dan membantu anak mengembangkan dirinya baik itu dari perkembangan kognitif, motorik, kreativitas, bahasa serta sosial-emosionalnya.

Penelitian ini bertujuan untuk memperoleh gambaran tentang seberapa besar pengaruh permainan tradisional engklek dalam meningkatkan perkembangan kognitif anak. Permainan tradisional engklek ini, selain untuk memenuhi kebutuhan naluri bermain anak, juga dapat menjadi sumber belajar yang sangat membantu anak dalam mengembangkan aspekaspek perkembangan anak, dimana aspekaspek tersebut harus dikembangkan sehingga anak akan lebih siap menghadapi lingkungan dan dapat lebih mudah mengikuti jenjang pendidikan yang lebih tinggi. Dalam bermain engklek ini akan tercipta kepribadian yang negatif menjadi positif misalnya anak yang tadinya kurang bersosialisasi dengan teman menjadi anak yang bisa sosialisasi, yang tadinya penakut menjadi tidak takut dan masih banyak hal lainnya.

Pengalaman-pengalaman yang diperoleh anak secara tidak langsung akan tertanam pada diri sesorang anak. Orang tua dan pendidik wajib mengerti karakteristik-karakteristik anak usia dini, supaya segala bentuk perkembangan anak dapat terpantau dengan baik. Berikut ini adalah beberapa karaktersitik anak usia dini menurut berbagai pendapat (Muhammad, 2012:56) :

1) Unik, yaitu sifat anak itu berbeda satu dengan yang lainnya. anak memiliki bawaan, minat, kapabilitas dan latar belakang kehidupan masing-masing.

2) Egosentris, yaitu anak lebih cenderung melihat dan memahami sesuatu itu penting sepanjang hal tersebut terkait dengan dirinya.

3) Aktif dan energik, yaitu anak lazimnya senang melakukan berbagai aktivitas, selama terjaga dari tidur, anak seolah-olah tidak pernah lelah, tidak pernah bosan, dan tidak pernah berhenti beraktivitas. Terlebih lagi kalau anak dihadapkan pada sesuatu kegiatan yang baru dan menantang.

4) Rasa ingin tahu yang kuat dan antusias terhadap banyak hal, yaitu anak cenderung memperhatikan membicarakan dan mempertanyakan berbagai hal yang sempat dilihat dan didengarnya, terutama terhadap hal-hal yang baru.

5) Spontan, yaitu perilaku yang ditampilkan anak umumnya relatif asli dan tidak di tutuptutupi sehingga merefleksikan apa yang ada dalam persaan dan pikirannya.

6) Senang dan kaya akan fantasi, yaitu anak senang dengan hal-hal yang imajinatif. Anak tidak saja senang dengan cerita-cerita khayal yang disampaikan oleh orang lain, tetapi anak sendiri juga senang bercerita kepada orang lain, tetapi anak sendiri juga senang bercerita kepada orang lain.

7) Masih mudah frustasi, yaitu anak masih mudah kecewa bila menghadapi sesuatu yang tidak memuaskan. Anak mudah menangis dan marah bila keinginannya tidak terpenuhi.

8) Masih kurang pertimbangan dalam melakukan sesuatu, yaitu anak 
belum memiliki pertimbangan yang matang, termasuk berkenaan dengan halhal yang membahayakannya.

9) Daya perhatian yang pendek, yaitu anak lazimnya memiliki daya perhatian yang pendek, terkecuali terhadap hal-hal yang secara instrinsik menarik dan menyenangkan.

10) Bergairah untuk belajar dan banyak belajar dari pengalaman, yaitu anak senang melakukan berbagai aktivitas yang menyebabkan terjadinya perubahan tingkah laku pada dirinya.

11) Semakin menunjukkan minat terhadap teman, yaitu anak mulai menunjukkan untuk bekerja sama dan berhubungan dengan teman-temannya.

\section{METODE PENELITIAN}

Metode penelitian diartikan sebagai cara ilmiah untuk mendapatkan data dengan tujuan dan kegunaan tertentu (Sugiyono, 2015: 3). Pendekatan yang digunakan dalam penelitian ini adalah pendekatan kuantitatif dengan menggunakan metode penelitian Experiment. Penelitian kuantitatif dipilih karena penelitian ini dilakukan untuk membuktikan bahwa permainan tradisional engklek dapat berepengaruh terhadap perkembangan kognitif anak usia 5-6 tahun di TK Tarbiyatul Athfal Desa Jaddih Kecamatan Socah Kabuaten Bangkalan.

Metode penelitian eksperimen dapat diartikan sebagai metode penelitian yang digunakan untuk mencari pengaruh perlakuan tertentu terhadap yang lain dalam kondisi yang terkendalikan (Sugiyono, 2015: 107). Desain penelitian ini menggunakan (pre-exsperimental design), karena desain ini belum merupakan eksperimen sungguh-sunguh melainkan masih terdapat variabel luar yang ikut berpengaruh terhadap bentuknya variabel dependen. Hal ini dapat terjadi, karena tidak adanya variabel kontrol, dan sampel tidak dipilih secara random (Sugiyono, 2015: 109). Jenis penelitian yang digunakan oleh peneliti yaitu jenis One-Group Pretest-Posttest Design, dimana dalam penelitiannya terdapat pretest dan post test yang dilakukan untuk mengetahui dan membandingkan perkembangan kognitif sebelum dan sesudah diberi perlakuan. Sehingga hasil dari perlakuan dapat diketahui dengan akurat. Adapun rancangan desain penelitian sebagai berikut:

\begin{tabular}{|c|c|c|}
\hline $\begin{array}{c}\text { Pre- } \\
\text { Test }\end{array}$ & VariabelTerikat & $\begin{array}{c}\text { Post } \\
\text { Test }\end{array}$ \\
\hline $\mathrm{O}_{1}$ & $\mathrm{X}$ & $\mathrm{O}_{2}$ \\
\hline
\end{tabular}

\section{Bagan Desain One Group Pretest-Posttest}

Keterangan:

$\mathrm{O}_{1}=$ nilai pretest (sebelum diberi perlakuan)

$\mathrm{X}=$ treatment yang diberikan

(Variabel independen)

$\mathrm{O}_{2}=$ nilai posttest (setelah diberi perlakuan)

Metode penelitian eksperimen dipilih oleh peneliti karena dalam penelitian peneliti akan mengukur pengaruh dari permainan tradisional engklek terhadap perkembangan kognitf anak. Sedangkan desain penelitian yang dipilih peneliti adalah desain penelitian preeksperimental, dikarenakan penelitian yang dilakukan peneliti tidak menggunakan kelas kontrol. Selain itu dalam penelitian ini tidak menggunakan sampel random melainkan menggunakan sampel jenuh yaitu semua sampel digunakan tidak dipilih secara acak.

Populasi dalam penelitian ini adalah anak usia 5-6 tahun yang ada di kelompok B denga jumlah anak 15 di TK Tarbiyatul Athfal Desa Jaddih Kecamatan Socah Kabuaten Bangkalan. Sampel dalam penelitian ini yaitu menggunakan 11 anak dengan menggunakan sampling purposive yang artinya teknik penentuan sampel dengan pertimbangan tertentu.

Teknik pengumpulan data yang digunakan dalam penelitian ini adalah observasi dan dokumentasi. Adapun pada penelitian yang akan dilaksankan oleh peneliti yaitu menggunakan teknik observasi partisipan. Dimana teknik ini peneliti terlibat langsung dengan aktivitas orang-orang yang sedang diamati, maka observasi partisipan peneliti tidak terlibat dan hanya sebagai pengamat independen. Peneliti hanya mencatat, menganalisis dan membuat kesimpulan tentang subjek yang diamati. Subjek dalam penelitian ini yaitu pengaruh permainan tradisional engklek terhdap kemampuan kognitif anak usia 5-6 tahun di TK Tarbiyatul Athfal Desa Jaddih Kecamatan Socah Kabupaten Bangkalan.

Penelitian ini akan menggunakan skala pengukur instrumen yang digunakan sebagai pengumpulan data dalam suatu penelitian dapat berupa lembar observasi. Skala pengukur 
instrumen adalah "menentukan satuan yang diperoleh, sekaligus jenis data atau tingkatan data, apakah data tersebut berjenis nominal, ordinal, interval, maupun rasio" (Siregar, 2015: 50). Penelitian ini peneliti menggunakan pedoman observasi dengan daftar check/checklist dengan menggunakan 4 opsi yaitu belum berkembang, mulai berkembang, mulai berkembang, berkembang sesuai harapan, dan berkembang sangat baik.

Dokumentasi memiliki fungsi sebagai alat yang dapat digunakan untuk memperjelas data yang diperoleh. Untuk mendukung proses dokumentasi, maka diperlukan alat bantu seperti kamera dan buku catatan. Data-data mengenai penilaian tentang kemampuan anak mengenal, menyebutkan dan mencocokkan bilangan dengan lambang bilangan 1-20 di TK Tarbiyatul Athfal, berupa hasil belajar dan RPPH.

\section{HASIL DAN PEMBAHASAN}

Penelitian ini dilaksanakan di TK Tarbiyatul Athfal Desa Jaddih Kecamatan Socah Kabupaten Bangkalan pada semester ganjil tahun ajaran 2017/2018. Sesuai dengan tujuan penelitian yang telah dirumuskan penelitian ini bertujuan untuk mengetahui pengaruh permainan tradisional engklek terhadap perkembangan kognitif anak usia 5-6 tahun dengan menyebutkan lambang bilangan 1-20 dan mencocokkan bilangan dengan lambang bilangan 1-20.

Perlakuan yang diberikan berupa penerapan permainan tradisional untuk mengajarkan anak tentang lambang bilangan yang dilakukan sebanyak dua kali sebelum perlakuan (treatment) diberikan. Subyek penelitian diberikan pretest untuk mengetahui kemampuan awal sebelum perlakuan. Setelah perlakuan selesai diberikan kepada anak, maka dilakukan penilaian akhir (posttest) dengan menggunakan instrumen yang sama, yaitu instrumen observasi untuk melihat perkembangan kognitif anak usia 5-6 tahun dalam menyebutkan dan mencocokkan.

Indikator kognitif di dalam Standar Tingkat Pencapaian Perkembangan Anak (STPPA) meliputi berfikir pemecahan masalah, berfikir logis, dan berfikir simbolik. Pada berfikir simbolik dengan indikator menyebutkan lambang bilangan 1-20 dan mencocokkan bilangan dengan lambang bilangan. Indikator ini kemudian dikembangkan dan disesuaikan dengan kebutuhan peneliti menjadi 6 butir pernyataan dimana dari setiap indikator terdapat 3 butir pernyataan.

Butir pernyataan tersebut diantaranya anak mampu menyebutkan lambang bilangan 1-20, mampu menyebutkan lambang bilangan 1-20 secara berurutan, mampu menyebutkan bilangan 1-20 sesuai gacuk yang dilempar oleh anak, mampu mencocokkan bilangan dengan lambang bilangan dengan tepat, mencocokkan bilangan dengan lambang bilangan 1-20 dengan melempar gacuk yang memiliki jumlah gambar yang sesuai pada kotak engklek secara berurutan, dan mampu mencocokkan bilangan dengan lambang bilangan 1-20 dengan melempar gacuk yang memiliki jumlah gambar yang sesuai pada kotak engklek secara acak. Instrumen pernyataan tersebut digunakan sebagai acuan pada pelaksanaan penilaian awal (pretest) dan pelaksanaan penilaian perkembangan kognitif pada saat setelah diberikan perlakuan (posttest).

Kegiatan observasi sebelum melakukan perlakuan (treatment) dilakukan sebanyak 2 kali, yaitu observasi pertama dilakukan pada hari Rabu 22 November 2017, observasi kedua dilakukan pada hari Kamis 23 November 2017. Observasi tersebut dilakukan untuk mengamati perkembangan kognitif anak dalam aspek berfikir simbolik dengan menggunakan pedoman observasi yang telah ditentukan. Adapun kegiatan yang dilakukan meliputi menyebutkan lambang bilangan 1-20 dan mencocokkan bilangan dengan lambang bilangan 1-20. Kegiatan tersebut dilakukan dan diteliti pada kegiatan inti, saat kegiatan belajar mengajar berlangsung di dalam kelas seperti yang telah tersusun di rencana kegiatan pembelajaran harian di TK Tarbiyatul Athfal Kec.Socah Kab.Bangkalan yaitu dengan penggunaan LKA dan media engeklek yang terbuat dari kertas.

Pelaksanaannya disesuaikan dengan RPPH yang telah dibuat dan disepakati oleh guru, peneliti dan atas izin kepala sekolah. Pemberian perlakuan (treatment) menggunakan permainan tradisional engklek yang dilakukan selama 2 kali.

1) Perlakuan (treatment) pertama dilaksanakan pada hari jum'at pada tanggal 24 November 2017. Kegiatan yang dilakukan adalah dengan pengenalan angka 1-20 dengan menggunakan permainan tradisional engklek. Guru menjelaskan lambang bilangan yang terdapat pada kotak engklek serta cara bermain engklek tersebut. Cara 
bermain engklek pada treatment pertama yaitu anak melempar gacuk sehingga tepat pada kotak. Kemudian anak disuruh menyebutkan terlebih dahulu gacuk tersebut berada tepat dikotak berapa. Setelah anak menyebutkan lambang bilangannya, barulah anak bermain engklek dengan melompati kotak satu persatu dengan menggunakan satu kaki. Kegiatan ini dilakukan secara bergantian setiap anak.

2) Perlakuan (treatment) kedua dilaksanakan pada hari Sabtu 25 November 2017. Kegiatan yang dilakukan pada treatment kedua sama dengan yang dilakukan pada treatment pertama. Namun jika pada treatment pertama hanya menyebutkan lambang bilangan sesuai gacuk yang dilempar, pada treatment kedua ini menyebutkan terlebih dahulu jumlah gacuk yang terdapat pada gambar tanaman dan barulah anak melempar gacuk sesuai jumlah gambar pada kotak engklek dengan tepat.

Berdasarkan hasil observasi diketahui bahwa penilaian anak sebelum dilakukan treatment adalah terdapat 2 anak tergolong belum berkembang (BB) dan 9anak tergolong mulai berkembang (MB). Setelah pelaksanaan treatment dengan menggunakan permainan tradisional engklek tehadap perkembangan kognitif anak usia 5-6 tahun mengalami perubahan menjadi lebih baik yakni terdapat 2 anak masuk dalam kategori mulai berkembang (MB), 5 anak masuk dalam kategori berkembang sesuai harapan (BSH), dan 4 anak masuk dalam kategori berkembang sangat baik (BSB).

Tabel 1

Hasil Pretest

\begin{tabular}{|c|c|c|}
\hline Nama & $\begin{array}{c}\text { Jumlah Rata-Rata } \\
\text { Hasil Pengamatan }\end{array}$ & Kriteria \\
\hline MY & 1.83 & MB \\
\hline IF & 1.00 & BB \\
\hline HRS & 2.00 & MB \\
\hline HMI & 1.42 & BB \\
\hline ADR & 2.08 & MB \\
\hline RH & 2.00 & MB \\
\hline WHY & 1.83 & MB \\
\hline RHT & 2.00 & MB \\
\hline NF & 1.83 & MB \\
\hline IML & 1.92 & MB \\
\hline RN & 2.17 & MB \\
\hline
\end{tabular}

Tabel 2

Hasil Postest

\begin{tabular}{|c|c|c|}
\hline Nama & $\begin{array}{c}\text { Jumlah Rata-Rata } \\
\text { Hasil Pengamatan }\end{array}$ & Kriteria \\
\hline MY & 3.00 & BSH \\
\hline IF & 2.17 & MB \\
\hline HRS & 3.17 & BSH \\
\hline HMI & 2.17 & MB \\
\hline ADR & 3.42 & BSB \\
\hline RH & 3.67 & BSB \\
\hline WHY & 3.08 & BSH \\
\hline RHT & 3.67 & BSB \\
\hline NF & 3.08 & BSH \\
\hline IML & 3.00 & BSH \\
\hline RN & 3.75 & BSB \\
\hline
\end{tabular}

Tabel 3

Hasil Peningkatan

\begin{tabular}{|c|c|c|c|}
\hline Nama & Pretest & Posttest & Peningkatan \\
\hline MY & 1.83 & 3.00 & 1.17 \\
\hline IF & 1.00 & 2.17 & 1.17 \\
\hline HRS & 2.00 & 3.17 & 1.17 \\
\hline HMI & 1.42 & 2.17 & 0.75 \\
\hline ADR & 2.08 & 3.42 & 1.34 \\
\hline RH & 2.00 & 3.67 & 1.67 \\
\hline WHY & 1.83 & 3.08 & 1.25 \\
\hline RHT & 2.00 & 3.67 & 1.67 \\
\hline NF & 1.83 & 3.08 & 1.25 \\
\hline IML & 1.92 & 3.00 & 1.08 \\
\hline RN & 2.17 & 3.75 & 1.58 \\
\hline
\end{tabular}

Setelah diketahui hasil observasi yang dilakukan dilakukan pengujian normalitas untuk mengetahui apakah data yang diperoleh berdistribusi normal atau tidak normal. Uji normalitas yang digunakan pada penelitian ini adalah uji Liliefors dikarenakan subjek penelitian berjumlah kurang dari 30 anak.

Tabel 1

Hasil Uji Normalitas

\begin{tabular}{|l|c|c|}
\hline \multicolumn{1}{|c|}{ Variabel } & $\begin{array}{c}\text { L hitung } \\
\text { tertinggi }\end{array}$ & L tabel \\
\hline Pretest & 0,1281 & 0,249 \\
\hline Posttest & 0,1921 & 0,249 \\
\hline
\end{tabular}


Variabel Pretest berdistribusi normal, jika $\mathrm{L}_{\text {hitumg }} \leq \mathrm{L}_{\text {tabel. }}$ Pada variabel Pretest dengan taraf signifikan 0,05 diperoleh nilai $\mathrm{L}_{\text {hitumg }}$ tertinggi sebesar 0,1281 sedangkan $\mathrm{L}_{\text {tabel }}$ sebesar 0,249. Sehingga nilai $\mathrm{L}_{\text {hitumg }} \leq \mathrm{L}_{\text {tabel. }}$. Berdasarkan hasil tersebut, maka dapat disimpulkan bahwa $\mathrm{H}_{0}$ diterima. Artinya data Pretest berdistribusi normal.

Variabel Posttest berdistribusi normal, jika $\mathrm{L}_{\text {hitumg }} \leq \mathrm{L}_{\text {tabel. }}$ Pada variabel Posttest dengan taraf signifikan 0,05 diperoleh nilai $\mathrm{L}_{\text {hitumg }}$ tertinggi sebesar 0,1921 sedangkan $\mathrm{L}_{\text {tabel }}$ sebesar 0,249 . Sehingga nilai $\mathrm{L}_{\text {hitumg }} \leq \mathrm{L}_{\text {tabel. }}$ Berdasarkan hasil tersebut, maka dapat disimpulkan bahwa $\mathrm{H}_{0}$ diterima dan $\mathrm{H}_{\mathrm{a}}$ ditolak. Artinya data variabel Posttest berdistribusi normal. Kedua variabel berdistribusi normal, sehingga persyaratan terpenuhi dan dapat melanjutkan pengolahan data menggunakan uji-t. Uji t menggunakan uji homogenitas dan uji lineritas.

Berdasarkan uji homogentitas dapat diketahui $F_{\text {hitung }} \leq F_{\text {tahel }}$ dengan nilai $1,58 \leq$ 2,98 maka $\mathrm{H}_{0}$ diterima, sehingga data dinyatakan homogen atau memiliki varian yang sama dan dapat dilanjutkan untuk pengujian hipotesis. Sedangkan pada uji linieritas data diperoleh hasil $F_{\text {hitung }}$ sebesar 0,29 dan $F_{\text {tabel }}$ sebesar 3,29. Berdasarkan data tersebut dapat disimpulkan bahwa $F_{\text {hitung }} \leq F_{\text {tahel }}$ yang artinya $\mathrm{H}_{0}$ diterima dan data berpola linier. Data berpola linier sehingga telah memenuhi syarat dan analisis korelasi serta uji-t dapat dilakukan.

Sebelum masuk pada uji-t, peneliti terlebih dahulu menganalisis data menggunakan korelasi product moment. Uji ini bertujuan untuk mengetahui bagaimana nilai korelasi antara dua sampel dengan menghitung nilai $r$ terlebih dahulu dengan menggunakan rumus Korelasi Pearson Product Moment sebagai berikut:

$$
r_{\text {hitung }}=\frac{n\left(\sum X Y\right)-\left(\sum X\right) \cdot\left(\sum Y\right)}{\sqrt{\left(n \cdot \sum X^{2}-\left(\sum X\right)^{2}\right) \cdot\left(n \cdot \sum Y^{2}-\left(\sum Y\right)^{2}\right)}}
$$

Keterangan:

$r_{\text {hitung }}=$ koefisien korelasi

$\sum \mathrm{X}=$ Jumlah skor total variabel $\mathrm{X}$

$\sum \mathrm{Y}=$ Jumlah skor total variabel $\mathrm{Y}$

$\sum X Y=$ Jumlah skor total variabel $\mathrm{X}$ dikali variabel $\mathrm{Y}$ $\sum \mathrm{X}^{2}=$ Jumlah skor total variabel $\mathrm{X}$ kuadrat

$\sum \mathrm{Y}^{2} \quad$ Jumlah skor total variabel Y kuadrat $n \quad=$ Jumlah responden

Hasil perhitungan korelasi yang telah dilakukan dapat diketahui sebesar 0,26 maka dapat diartikan bahwa koefisien korelasi yang didapat termasuk dalam kategori sangat kuat.

$\mathrm{KP}=r^{2} \times 100 \%=(0,93)^{2} \times 100 \%=93 \%$

Keterangan:

$\mathrm{KP}=$ Nilai koefisien determinan

$r \quad=$ nilai koefisien korelasi

Berdasarkan hasil perhitungan koefisien determinasi diatas, dapat disimpulkan bahwa kontribusi permainan tradisional engklek terhadap perkembangan kognitif anak usia 5-6 tahun di TK Tarbiyatul Athfal Desa Jaddih Kecamatan Socah Kabupaten Bangkalan sebesar 93\%, selebihnya $7 \%$ dipengaruhi oleh faktor lain.

Perhitungan analisis data dalam penelitian ini menggunakan uji-t (t-test). Tujuan uji $t$ adalah untuk mengetahui ada tidaknya pengaruh atau perbedaan nilai ratarata antara dua kelompok data yang berpasangan. Penggunaan uji-t dua variabel dapat digunakan dengan rumus sebagai berikut:

$$
t=\frac{\bar{x}_{1}-\bar{x}_{2}}{\sqrt{\frac{s_{1}{ }^{2}}{n_{1}}+\frac{s_{2}{ }^{2}}{n_{2}}-2 r\left(\frac{s_{1}}{\sqrt{n_{1}}}\right)\left(\frac{s_{2}}{\sqrt{n_{2}}}\right)}}
$$

Keterangan:

$\overline{x_{1}} \quad=$ rata-rata pretest

$\overline{x_{2}} \quad=$ rata-rata posttest

$s_{1} \quad=$ simpangan baku pretest

$s_{2} \quad=$ simpangan baku posttest

$s_{1}{ }^{2}=$ varians pretest

$s_{2}{ }^{2}=$ varians postest

$r \quad=$ korelasi antara 2 sampel

Hipotesis analisis data adalah sebagai berikut :

Ho : Tidak ada pengaruh permainan tradisional engklek terhadap perkembangan kognitif anak usia 5-6 tahun 
Ha : Ada pengaruh pengaruh permainan tradisional engklek terhadap perkembangan kognitif anak usia 5-6 tahun

Taraf Kesalahan pengujian analisis data $\alpha=$ $0,05(5 \%)$. Jika $-t_{\text {tabel }} \leq t_{\text {hitung }} \leq t_{\text {tabel }}$, maka $\mathrm{H}_{0}$ diterima, sehingga tidak ada pengaruh permainan tradisional engklek terhadap perkembangan kognitif anak usia 5-6 tahun. Jika -t tabel $>$ thitung $>$ tabel, maka $\mathrm{H}_{0}$ ditolak dan Ha diterima sehingga ada pengaruh pengaruh permainan tradisional engklek terhadap perkembangan kognitif anak usia 5-6 tahun.

Berdasarkan perhitungan analisis data diatas diperoleh nilai thitung sebesar -5,83 dan $t_{\text {tabel }}$ sebesar 2,086. Maka dapat disimpulkan bahwa $-t_{\text {tabel }}>t_{\text {hitung }}(-2,086>-5,83)$ sehingga $\mathrm{HO}$ ditolak dan Ha diterima yang berarti terdapat pengaruh permainan tradisional engklek terhadap perkembangan kognitif anak usia 5-6 tahun di TK Tarbiyatul Athfal Desa Jaddih Kecamatan Socah Kabupaten Bangkalan.

\section{Pembahasan}

Perlakuan yang diberikan berupa penerapan permainan tradisional untuk mengajarkan anak tentang lambang bilangan yang dilakukan sebanyak dua kali sebelum perlakuan (treatment) diberikan. Subyek penelitian diberikan pretest untuk mengetahui kemampuan awal sebelum perlakuan. Setelah perlakuan selesai diberikan kepada anak, maka dilakukan penilaian akhir (posttest) dengan menggunakan instrumen yang sama, yaitu instrumen observasi untuk melihat perkembangan kognitif anak usia 5-6 tahun dalam menyebutkan dan mencocokkan.

Penggunaan permainan tradisional engklek dalam mengasah perkembangan kognitif dalam hal mengenal lambang bilangan dilakukan dengan cara menyebutkan lambang bilangan dan mencocokkan bilangan dengan lambang bilangan 1-20. Menurut Nisa' dan Karim (2017:53) Dimana bilangan merupakan salah satu konsep matematika yang dilambangkan dengan simbol-simbol yang berupa angka. Sementara untuk lambang bilangan merupakan suatu simbol ataupun lambang yang digunakan untuk mewakili suatu bilangan yang disebut sebagai angka.
Untuk mengembangkan kemampuan anak, khususnya kemampuan kognitif matematika, dibutuhkan lingkungan dan sumber belajar yang menyenangkan. (Nisa' dan Karim, 2017: 127). Hal ini bertujuan untuk menumbuhkan sikap positif dan minat yang tinggi terhadap pembelajaran matematika. Dalam penelitian ini peneliti menggunakan permainan tradisional engklek sebagai lingkungan dan sumber belajar yang menyenangkan.

Indikator kognitif di dalam Standar Tingkat Pencapaian Perkembangan Anak (STPPA) meliputi berfikir pemecahan masalah, berfikir logis, dan berfikir simbolik. Pada berfikir simbolik dengan indikator menyebutkan lambang bilangan 1-20 dan mencocokkan bilangan dengan lambang bilangan.72 Indikator ini kemudian dikembangkan dan disesuaikan dengan kebutuhan peneliti menjadi 6 butir pernyataan dimana dari setiap indikator terdapat 3 butir pernyataan.

Berdasarkan observasi sebelum dilakukan treatment menunjukkan bahwa anak belum bisa menyebutkan lambang bilangan 1-20 secara tepat. Ada anak yang hanya dapat menyebutkannya 1-10 saja yang benar untuk 1120 masih kebalik-kebalik. Namun terdapat pula anak yang sudah dapat menyebutkan 1-20 dengan tepat, ketika diminta untuk menunjukkan lambang bilangannya anak masih bingung. Padahal seharusnya pada anak usia 5-6 tahun sesuai dengan standar tingkat pencapaian perkembangan anak (STPPA) anak sudah dapat menyebutkan lambang bilangan 120 dan sudah dapat mencocokan bilangan dengan lambang bilangan. Oleh sebab itu anak yang belum mencapai tingkat perkembangannya sesuai usia mereka perlu diberikan rangsangan atau stimulus yang lebih, agar anak dapat mencapai tingkat perkembangannya dengan maksimal.

Ketika pelaksanaan treatment anak antusias dan tertarik dengan kegiatan yang diberikan oleh pendidik. Sehingga anak menikmati dan menyesuaikan diri dengan peraturan yang diberikan dalam pembelajaran. Ketika kegiatan treatment anak sudah mualai bisa menyebutkan lambang bilangan 1-20 dan mencocokkan bilangan dengan lambang bilangan. Pernyataan ini sesuai dengan tingkat pencapaian perkembangan anak (STPPA) dalam perkembangan kognitif.

Setelah kegiatan treatment berakhir anak sudah mampu menyebutkan dan mencocokkan lambang bilangan. Hal ini dibuktikan dengan hasil observasi setelah dilakukan teratment, 
anak mampu menyebutkan lambang bilangan 120 baik itu tanpa bermaian engklek ataupun ketika bermain engklek. Selain itu anak juga sudah mampu mencocokkan bilangan dengan lambang bilangan terbukti ketika anak mampu mencocokkan bilangan yang terdapat pada gacuk yang di cocokkan dengan kotak engklek tanpa kesalahan dan tanpa bantuan guru.

Berdasarkan paparan diatas diketahui penggunaan permainan tradisional engklek pada anak usia 5-6 tahun berpengaruh pada perkembangan kognitif anak usia dini. Karena melalui bermain, anak akan belajar berbagai hal yang ada disekelilingnya. Bermain adalah tahap awal dari proses panjang belajar pada anak-anak yang dialami oleh semua manusia. Melalui bermain yang menyenangkan anak menyelidiki dan memperoleh pengalaman yang kaya baik dengan dirinya sendiri, lingkungan maupun orang lain disekitarnya. Sehingga anak akan mengorganisasikan berbagai pengalaman dan kemampuan kognitifnya untuk menyusun kembali ide-idenya.

Bermain penting bagi perkembangan kognitif anak yaitu sebagai cara untuk mengasimilasikan informasi-informasi baru dengan pengalamanpengalaman masa lalu lewat pengertian yang sifatnya simbolik (Kurniati, 2016: 6). Pengalaman masa lalu bisa dimaksudkan seperti anak belajar dari kegiatan yang biasa dilakukan anak dengan bermain permainan tradisional yang diwariskan nenek moyang. Oleh karena itu akan dijabarkan bagaimana hasil pretest dan posttest yang dilakukan dalam penelitian ini.

Selama kegiatan Pretest (sebelum perlakuan/treatment) masih terdapat 2 anak masuk dalam kategori belum berkembang (BB) dengan rata-rata $1,00-1,42$ pada penilaian pretest dua pengamat yang artinya anak belum bisa menyebutkan secara benar dan mencocokkan bilangan dengan lambang bilangan dengan tepat. Selain itu terdapat 9 anak masuk dalam kategori mulai berkembang (MB) dengan ratarata $1,83-2,17$ pada penilaian pretest dua pengamat yang artinya anak mulai bisa menyebutkan namun masih salah dalam urutannya dan dalam mencocokkan masih terdapat kesalahan.

Kegiatan selanjutnya yaitu kegiatan pengambilan data sesudah perlakuan atau posttest yang dilakukan menggunakan permainan tradisional engklek. Dalam butir pernyataan pertama dari indikator 1 yaitu anak diminta untuk menyebutkan lambang bilangan
1-20 melaui kotak engklek. Berdasarkan kegiatan yang telah dilakukan dapat diketahui dari pengamat 1 dan pengamat 2 bahwa 2 anak masuk dalam kategori mulai berkembang (MB) dengan rata-rata 2 pada rekapitulasi pretest yang artinya anak mulai bisa menyebutkan lambang bilangan 1-20 sambil melihat kotak engklek yang terdapat lambang bilangan. Terdapat 5 anak masuk dalam kategori berkembang sesuai harapan (BSH) dengan rata-rata 3 pada rekapitulasi pretest yang artinya anak mampu menyebutkan lambang bilangan 1-20 tanpa melihat kotak engklek, namun beberapa lambang bilangan yang disebutkan masih dibantu oleh guru.

Terdapat pula 4 anak masuk dalam kategori berkembang sangat baik (BSB) dengan rata-rata 4 pada rekapitulasi pretest yang artinya anak mampu menyebutkan lambang bilangan 1-20 tanpa melihat kotak engklek, tidak pula dibantu oleh guru serta dalam menyebutkannya benar tanpa adanya kesalahan. Hal ini senada dengan ungkapan Yulani Nurani Sujiono dalam Suyadi dan Dahlia bahwa anak usia dini adalah sosok individu yang sedang menjalani suatu proses perkembangan dengan pesat dan fundamental bagi kehidupan selanjutnya (Suyadi dan Dahlia, 2015: 28). Dimana anak membutuhkan sebuah proses dalam perkembangannya, untuk itu pendidik lebih mengasah perkembangan anak dengan memberikan pembelajaran mengenai bilangan menggunakan media yang menarik taupun kegiatan yang menarik bagi anak usia dini.

Butir pernyataan kedua dari indikator 1 adalah menyebutkan lambang bilangan 1-20 secara berurutan. Kegiatan pada butir pernyataan ini sama halnya dengan butir pernyataan pertama. Namun pada kegiatan ini anak diminta menyebutkan lambang bilangan yang terdapat pada kotak engklek selain itu anak diminta untuk menyebutkan jumlah gambar yang terdapat pada gacuk. Berdasarkan pernyataan kedua ini diketahui dari hasil pengamat 1 dan pengamat 2 yaitu terdapat 2 anak masuk dalam kategori mulai berkembang (MB) dengan rata-rata 2 pada rekapitulasi posttest yang artinya anak mulai bisa menyebutkan lambang bilangan terdapat pada kotak engklek dan pada gacuk, tetapi masih dituntun oleh guru. Terdapat 7 anak masuk dalam kategori berkembang sesuai harapan (BSH) dengan rata-rata 3-3,5 pada rekapitulasi pretest yang artinya anak mampu menyebutkan lambang bilangan pada kotak engklek dan pada 
jumlah gambar yang terdapat pada gacuk dengan bantuan guru, tetapi tidak semua lambang bilangan dibantu oleh guru.

Terdapat pula 2 anak masuk dalam kategori berkembang sangat baik (BSB) dengan rata-rata 4 pada rekapitulasi pretest yang artinya anak mampu menyebutkan lambang bilangan pada kotak engklek dan pada jumlah gambar pada gacuk tanpa kesalahan. Hal ini senada dengan perkembangan kognitif anak usia 5-6 tahun, dimana untuk mengasah perkembangan kognitif perlu adanya kegiatan atau proses memperoleh pengetahuan melalui pengalamannya sendiri (Wiyani, 2016:61). Oleh karena itu, dengan adanya kegiatan permainan tradisional engklek dalam mengasah perkembangan kognitif terdapat peningkatan pada perkembangan anak saat kegiatan pretest belum mampu setelah diberikan treatment melalui belajar sambil bermain anak mulai mampu menyebutkan lambang bilangan 1-20.

Butir pernyataan ketiga pada indikator 1 yaitu anak menyebutkan lambang bilangan sesuai gacuk yang dilempar oleh anak. Dalam kegiatan ini guru mengajak anak bermain engklek di halaman sekolah. Terlebih dahulu anak melempar gacuk pada kotak engklek yang telah dibuat guru di tanah.

Setelah anak melempar guru menanyakan jatuh pada kotak berapa engklek tersebut, kemudian anak menjawab. Setelah anak menjawab barulah anak bermain dengan melompati kotak engklek satu persatu menggunakan satu kaki.

Pernyatan ketiga ini diketahui hasilnya yaitu pengamat 1 dan pengamat 2 menunjukkan 2 anak masuk dalam kategori mulai berkembang (MB) dengan rata-rata 2,5 pada rekapitulasi posttest yang artinya anak bisa menyebutkan lambang bilangan pada kotak engklek yang dilempar oleh gacuk pada angka 1-10, namun pada angka 11-20 anak masih salah dalam menyebutkkannya. Selain itu terdapat 6 anak yang masuk dalam kategori berkembang sesuai harapan (BSH) degan rata-rata 3-3,5 pada rekapitulasi pretest yang artinya anak mampu menyebutkan lambang bilangan pada kotak engklek yang dilempar oleh gacuk, tetapi pada lambang bilangan 11-20 masih terdapat lambang bilangan yang dibantu oleh guru. Hal ini senada dengan pengertian anak usia dini dimana kesempatan emas bagi anak untuk belajar, pada usia ini anak memiliki rasa ingin tahu yang tinggi (Isjoni, 2014:61). Sehingga dalam kegiatan posttest anak mengalami peningkatan karena anak banyak bertanya pada guru melalui permainan tradisional engklek.

Butir pernyataan pertama dari indikator ke 2 yaitu anak mampu mencocokkan bilangan dengan lambang bilangan. Butir pernyataan ini memiliki kegitan sama dengan butir pernyataan ketiga dari indikator ke-2 di atas. Dimana anak diajak bermain engklek di halaman sekolah oleh guru. Kegiatan dalam butir pernyataan adalah anak mengambil gacuk sesuai keinginan anak, kemudian anak menghitung jumlah gambar yang terdapat pada gacuk. Setelah kegitan tersebut dilakukan anak menunjukkan pada guru mana lambang bilangan yang terdapat pada kotak engklek yang sesuai dengan gacuk yang diambil oleh anak. Kemudian anak melempar gacuk tersebut sesuai yang telah ditunjuk oleh anak, dan barulah anak bermain engklek dengan melompati kotak engklek satu persatu dengan satu kaki.

Butir pernyataan kegiatan ini diketahui hasil pengamatan dari pengamat 1 dan pengamat 2 yaitu terdapat 2 anak masuk dalam kategori mulai berkembang (MB) dengan rata-rata 2 pada rekapitulasi posttes yang artinya anak mampu menyebutkan jumlah gambar yang terdapat pada gacuk, namun anak belum mampu untuk mencocokkannya pada kotak engklek dengan cara menunjukkan terlebih dahulu baru dilemparkan. Terdapat pula 6 anak masuk dalam kategori berkembang sesuai harapan (BSH) dengan rata-rata 3-3,5 pada rekapitulasi posttest yang artinya anak mampu menyebutkan jumlah gambar yang terdapat pada gacuk serta anak dapat menunjukkan lambang bilangannya yang ada pada kotak engklek, namun terdapat bantuan guru dalam mencocokkannya dimana guru memberikan kode contohnya seperti angka 18, guru menyebutkan jika angka 8 merupakan dua donat.

Terdapat pula juga terdapat 3 anak masuk dalam kategori berkembang sangat baik (BSB) dengan rata-rata 4 pada rekapitulasi pretest dimana anak mampu mencocokkan jumlah gambar yang terdapat di gacuk dengan lambang bilangan pada kotak engklek tanpa tanpa kesalahan. Hal ini senada dengan ungkapkan Santrock bahwa permainan mampu meningkatkan perkembangan kognitif (Kurniati, 2016:4). Oleh karena itu kegiatan bermain suatu permainan menjadikan suatu alternatif bagi kegiatan belajar mengajar terbukti anak mengalami peningkatan dalam mengenal lambang bilangan melalui permainan tradisional engklek. 
Butir pernyataan kedua dari indikator ke-2 yaitu anak mampu mencocokkan bilangan dengan lambang bilangan dengan melempar gacuk yang sesuai dengan jumlah gambar pada gacuk dan dilemparkan pada kotak engklek yang sama pula dengan jumlah gambar pada gacuk. Butir pernytaan ini memiliki kegitan lanjutan dari butir pernyataan pertama dari indikator ke2. Dimana anak diajak bermain engklek dihalaman sekolah oleh guru. Namun cara bermainnya sedikit berbeda dalam melemparkan gacuk. Pada kegiatan sebelumnya anak terlebih dahulu menggambil gacuk secara berurutan dari yang terkecil kemudian anak menghitung jumlah gambar yang terdapat pada gacuk yang telah diambil.

Setelah anak mengetahui jumlah gambar tersebut barulah anak melemparkan pada kotak engklek yang memiliki lambang bilangan yang sesuai ataupun sama pada jumlah gambar yang terdapat pada gacuk. Barulah anak dapat bermain engklek dengan melompati kotak engklek secara satu persatu dengan menggunakan satu kaki. Butir pernyataan ini diketahui hasil pengamatan dari pengamat 1 dan pengamat 2 menyatakan terdapat 2 anak masuk dalam kategori mulai berkembang (MB) dengan rata-rata 2,5 pada rekapitulasi pretest yang artinya anak bisa mencocokkan jumlah gambar yang terdapat pada gacuk dengan lambang bilangan yang dikotak engklek, namun dalam mencocokkannya secara berurutan anak masih dapat mengurutkan lambang bilangan 1sampai 10.

Terdapat pula 9 anak masuk dalam kategori berkembang sesuai harapan (BSH) dengan ratarata 3-3,5 pada rekapitulasi posttest yang artinya anak mampu dalam mencocokkan bilangan yang terdapat pada gacuk dengan lambang bilangan yang terdapat pada kotak engklek, tetapi anak masih dalam bimbingan guru jika sudah pada lambang bilangan 15 sampai 20 . Hal ini tidak senada dengan ungkapan Ahmad dimana kemampuan lambang bilangan anak usia dini, dimana anak dapat menghitung sejumlah benda dan mencocokkannya (Ahmad, 2011:115). Untuk anak yang masih dalam kategori mulai berkembang perlu adanya bimbingan yang lebih dalam menegenal lambang bilangan.

Butir pernyataan ketiga dari indikator ke-2 yaitu anak mencocokkan bilangan dengan lambang bilangan 1-20 dengan melempar gacuk yang dilemparkan pada kotak engklek yang sesuai dengan jumlah gambar yang terdapat pada gacuk secara acak. Butir pernyataan ini kegitannya sama dengan butir pernyataan kedua dari indikator 2. Dimana anak mengambil gacuk secara acak kemudian anak terlebih dahulu menghitung jumlah gambar yang terdapat pada gacuk barulah anak melempar gacuk tersebut pada kotak engklek dengan lambang bilangan yang sesuai.

Kegitan ini dilakukan anak berkali-kali sampai anak dapat melemparkan gacuk 1-20. Hasil yang didapat pada pernyataan ini yaitu pengamat 1 dan pengamat 2 menunjukkan bahwa terdapat 2 anak masuk dalam kategori mulai berkembang (MB) dengan rata-rata 2 pada rekapitulasi posttest yang artinya anak mampu dalam mencocokkan bilangan yang terdapat pada gacuk dengan lambang bilangan pada kotak engklek secara acak dengan menyisihkan beberapa gacuk yang tidak dilempar. Terdapat 9 anak masuk dalam kategori berkembang sesuai harapan (BSH) yang artinya anak mampu mencocokkan bilangan dengan lambang bilangan 1-20 dengan melempar gacuk yang memiliki jumlah gambar yang sesuai pada kotak engklek secara acak tanpa menyisihkan gacuk yang di cocokkan dengan bantuan guru. Hal ini tidak senada dengan kemampuan lambang bilangan anak usia dini, dimana anak dapat menghitung sejumlah benda dan mencocokkannya (Ahmad, 2011:115). Untuk anak yang masih dalam kategori mulai berkembang perlu adanya bimbingan yang lebih dalam mengenal lambang bilangan.

Selama kegiatan Posttest (sesudah perlakuan/treatment) masih terdapat 2 anak masuk dalam kategori belum berkembang (MB) dengan rata-rata 2,17 dalam penilaian posttest dua pengamat yang artinya anak mampu mencocokkan bilangan pada gacuk dengan lambang bilangan pada kotak engklek dengan menyisihkan beberapa gacuk yang tidak dilempar. Terdapat 5 anak masuk dalam kategori berkembang sesuai harapan (BSH) dengan ratarata 2,8-3,08 dalam penilaian posttest dua pengamat yang artinya anak mampu mencocokkan bilangan dengan lambang bilangan 1-20 dengan melempar gacuk yang memiliki jumlah gambar yang sesuai pada kotak engklek secara berurutan dengan melempar semua gacuk yaitu bilangan 1-15 saja tanpa bantuan guru. Dan 4 anak masuk dalam kategori berkembang sangat baik (BSB) yang artinya anak mampu mencocokkan bilangan dengan lambang bilangan 1-20 dengan melempar gacuk yang memiliki jumlah gambar yang sesuai pada 
kotak engklek secara acak tanpa kesalahan dan dapat melemparkan semua gacuk tanpa tersisa.

Sebelumnya pada kegiatan pretest anak masih masuk dalam kategori mulai berkambang dan hanya 2 anak masuk dalam kategori belum berkembang (BB) dan 9 anak masuk dalam kategori mulai berkembang (MB). Namun setelah diberikan treatment ada perkembangan yang baik pada anak di TK Tarbiyatul Athfal. Hal ini diperkuat oleh ungkapan Yuliani Nurani Sujono dalam Suyadi dan Dahlia bahwa anak usia dini adalah sosok individu yang sedang menjalani suatu proses perkembangan dengan pesat dan fundamental bagi kehidupan selanjutnya (Suyadi dan Dahlia, 2015: 28). Oleh karena itu dengan adanya stimulus, anak akan mengalami suatu perkembangan yang begitu pesat, terutama dalam perkembangan kognitif anak dalam mengenal lambang bilangan 1-20. Hal ini dapat dibuktikan dari data yang telah diperoleh saat pretest dan posttest yang telah dilakukan oleh peneliti.

Anak memiliki dunia dan karakteristik sendiri yang jauh berbeda dari orang dewasa. Anak selalu aktif, dinamis, antusias, dan ingin tahu terhadap apa yang dilihat dan didengarnya, seolah-olah tidak pernah berhenti belajar. Anak juga bersifat egosentris, memiliki rasa ingin tahu secara alamiah unik, kaya dengan fantasi, memiliki daya perhatian yang pendek, dan merupakan masa yang paling potensial untuk belajar (Uyu dan Agustin, 2012: 7). Sesuai dengan pendapat yang dikemukakan diatas mengenai anak usia dini yang memiliki rasa ingi tahu apa yang dilihat dan didengarnya, terlihat ketika kegiatan bermain permainan tradisional engklek. Dimana guru menjelaskan cara bermain engklek mulai dari melempar gacuk dan lompat pada kotak engklek. Anak terlihat sangat serius mendengar dengan caraya sendiri. Ada yang mengikuti guru ketika mencontohkan bermain engklek dan ada pula anak yang hanya duduk sambil meilhat guru mencontohkannya. Sifat dan karakteristik anak berbeda-beda dalam menyerap informasi yang diberikan oleh guru. Oleh karena itu guru harus memahami semua karakter yang dimiliki anak didiknya.

Berdasarkan observasi sebelum dilakukan treatment menunjukkan bahwa anak belum bisa menyebutkan lambang bilangan 1-20 secara tepat. Ada anak yang hanya dapat menyebutkannya 1-10 saja yang benar untuk 1120 masih kebalik-kebalik. Namun terdapat pula anak yang sudah dapat menyebutkan 1-20 dengan tepat, ketika dimintak untuk menunjukkan lambang bilangannya anak masih bingung. Padahal seharusnya pada anak usia 5-6 tahun sesuai dengan standar tingkat pencapaian perkembangan anak (STPPA) anak sudah dapat menyebutkan lambang bilangan 1-20 dan sudah dapat mencocokan bilangan dengan lambang bilangan (Permendikbud No. 137, 2014). Oleh sebab itu anak yang belum menca pai tingkat perkembangannya sesuai usia mereka perlu diberikan rangsangan atau stimulus yang lebih, agar anak dapat mencapai tingkat perkembangannya dengan maksimal.

Ketika pelaksanaan treatment anak antusias dan tertarik dengan kegiatan yang diberikan oleh pendidik. Sehingga anak menikmati dan menyesuaikan diri dengan peraturan yang diberikan dalam pembelajaran. Ketika kegiatan treatment anak sudah mualai bisa menyebutkan lambang bilangan 1-20 dan mencocokkan bilangan dengan lambang bilangan. Pernyataan ini sesuai dengan tingkat pencapaian perkembangan anak (STPPA) dalam perkembangan kognitif.

Setelah kegiatan treatment berakhir anak sudah mampu menyebutkan dan mencocokkan lambang bilangan. Hal ini dibuktikan dengan hasil observasi setelah dilakukan teratment, anak mampu menyebutkan lambang bilangan 120 baik itu tanpa bermaian engklek ataupun ketika bermain engklek. Selain itu anak juga sudah mampu mencocokkan bilangan dengan lambang bilangan terbukti ketika anak mampu mencocokkan bilangan yang terdapat pada gacuk yang di cocokkan dengan kotak engklek tanpa kesalahan dan tanpa bantuan guru.

Setiap permainan memiliki kelebihan dan kekurangan masing-masing, baik itu permainan yang modern ataupun yang tradisional. Permainan modern menggunakan peralatan yang canggih untuk memainkannya dan bertempat diruangan khusus dan nyaman. Sedangkan untuk permainan tradisional yang hanya membutuhkan peralatan sederhana dengan memanfaatkan benda atau objek di lingkungan sekitar, seperti kayu, batu, bambu dan lain-lain (Mulyani, 2016:15). Pada penelitian ini saat melakukan treatment ataupun posttest di TK Tarbiyatul Atffal Desa Jaddih Kecamatan Socah Kabupaten Bangkalan ketika bermain engklek sudah dimiliki oleh lembaga, sehingga peneliti tidak perlu mengeluarkan biaya yang banyak. Serta untuk lokasi bermain, juga sudah tersedia dan memiliki halaman yang cukup luas. 


\section{SIMPULAN}

Berdasarkan hasil dan pembahasan penelitian ini dapat disimpulkan bahwa terdapat kemampuan dari permainan tradisional engklek terhadap perkembangan kognitif anak usia 5-6 tahun di TK Tarbiyatul Athfal Desa Jaddih Kecamatan Socah Kabupaten Bangkalan. Hal nilai $t_{\text {hitung }}$ sebesar 5,83 dan $t_{\text {tabel }}$ sebesar 2,086. Maka dapat disimpulkan bahwa $-t_{\text {tabel }}>t_{\text {hitung }}(-2,086>-5,83)$ sehingga $\mathrm{H}_{0}$ ditolak dan $\mathrm{H}_{\mathrm{a}}$ diterima yang berarti terdapat pengaruh permainan tradisional engklek terhadap perkembangan kognitif anak usia 5-6 tahun di TK Tarbiyatul Athfal Desa Jaddih Kecamatan Socah Kabupaten Bangkalan.

\section{Saran}

Berdasarkan simpulan dari hasil penelitian yang telah dilakukan oleh peneliti dan telah dipaparkan, maka disampaikan saran sebagai berikut:

1. Guru

a) Sebaiknya setiap guru memahami penanganan setiap anak

b) Sebaiknya guru lebih memanfaatkan media pembelajaran yang inovatif untuk anak seperti halnya penggunaan permainan tradisional yang digunakan dalam kegiatan pembelajaran.

2. Peneliti Selanjutnya

Bagi peneliti selanjutnya dapat mengembangkan permainan tradisional engklek misalnya terhadap perkembangan sosial-emosional karenakan saat kegiatan permainan berlangsung anak tidak sabar menunggu giliran dan dapat mengikuti peraturan bermain.

\section{DAFTAR PUSTAKA}

Ahmad, S. 2011. Perkembangan Anak Usia Dini. Jakarta: PT Kencana.

Aulina, C. N. 2014. Pengaruh Bermain Peran Terhadap Peningkatan Kemampuan Sosial Anak Usia Dini. Jurnal $P G$ PAUD Trunojoyo : Jurnal Pendidikan dan Pembelajaran Anak Usia Dini. Vol. 1, No. 1: 14-27.

Chasanah. 2015. Pengembangan Permainan Tradisional Gotri Untuk Pembelajaran Fisik Motorik Kasar Anak. Jurnal PG PAUD Trunojoyo : Jurnal Pendidikan dan Pembelajaran Anak Usia Dini. Vol. 2, No. 2: 87-94.

Desmita. 2015. Psikologi Perkembangan. Bandung: PT Remaja Rosdakarya

Fadlillah, M. 2014. Desain Pembelajaran PAUD. Jakarta: Ar-Ruzz Media.

Gian, P. 2015. Pengaruh Permainan Tradisional Bakiak dan Engklek terhdap Keterampilan Sosial Anak Usia Dini. Jurnal Pendidikan Anak Usia Dni. (online) diakeses 20-06-2015, http://jurnal.student.uny.ac.id/ujs/index .php/fiptp/articel.

Isjoni, H. 2014. Model-Model Pembelajaran Anak Usia Dini. Bandung: Alfabeta

Kurniati, E. 2016. Permainan Tradisional dan Perannya dalam Mengembangkan Keterampilan Sosial Anak. Jakarta: Prenadamedia Group.

Mulyani, N. 2016. Dasar-Dasar Pendidikan Anak Usia Dini. Yogyakarta: Kalimedia.

2016. Super Asyik Permainan Tradisional Anak Indonesia. Yogyakarta: Diva Pres

Nisa', T. F. dan Karim, M. B. 2017. Think Different. (Teori dan Praktik dalam Pembelajaran Matematika Anak Usia Dini). Surabaya: Pustaka Idea.

Peraturan Mentri Pendidikan dan Kebudayaan (Permendikbud) Republik Indonesia Indonesia Nomor 137 Tahun 2014 tentang kurukulum PAUD.

Siregar, S. 2015. Statistika Parametrik Untuk Penelitian Kuantitatif. Jakarta: PT Bumi Aksara.

Sugiyono, 2015. Metode Penelitian Pendidikan Pendekatan Kuantitatif, Cet 22. Bandung: Alfabeta

Susanto, A. 2011. Perkembangan Anak Usia DIni Pengantar dalam Berbagai Aspeknya. Jakarta: Kencana Prenadamedia Group.

Suyadi \& Dahlia. 2015. Implementasi dan Inovasi Kurikulum PAUD 2013. Bandung: PT Remaja Rosdakarya 
100 Jurnal PG-PAUD Trunojoyo : Jurnal Pendidikan dan Pembelajaran Anak Usia Dini, Volume

5, Nomor 2, Oktober 2018, hal 86-100

Triharso, A. 2013. Permainan Kreatif dan Edukatif untuk Anak Usia Dini 30 Permainan Matematika dan Sains. Yogyakarta: Andi Offest.

Uyu, W. \& Agustin, M. 2012. Penilaian Perkembangan Anak Usia Dini. Bandung: PT Refika Aditama.

Wiyani, N. A. 2014. Psikologi Perkembangan Anak Usia Dini. Yogyakarta: Gava Media. 